\title{
Enemy at the Gates
}

\section{Welcome by the Editor-in-Chief}

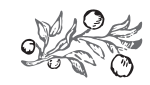

Journal of Economic Literature (JEL) codes: A1, B3, F6, H10

Keywords: economics, economic history, migration, Hungary

I have been repeatedly invited to deliver lectures at the conferences held at Balatonszárszó and Balatonlelle ever since the resuscitation of the Hungarian Reformed Church's Lyceum 25 years ago from the old traditions of the Teacher Training College of Sárospatak. This year's invitation also included a separate request regarding the content. "Please talk about the risks involved in the 2018 general elections and the external and internal dangers that lie ahead of us," I was told. It is not my habit to gainsay my brothers, especially on the 500th anniversary of the Reformation, so I did mention the masses of Asians and Africans congesting our borders in preparation for occupying Europe, and the threats and domestic problems they pose to us in my speech delivered to bishops and other church dignitaries gathered from Subcarpathia, the Partium, and other territories populated by Hungarians in the neighbouring countries and from overseas.

Aware of the nature of my address, to balance it in advance and to hearten the Calvinist congregation, I began my speech with the achievements of the rightist government and of the operations of the National Bank of Hungary in support of the Government's fiscal policy. I told them that next year's budget, adopted a few weeks earlier, allocates HUF 81 billion more for education, HUF 102 billion more for healthcare, HUF 287 billion more for the support of families, HUF 83 billion more for public security, and HUF 205 billion more for economic development than the budget approved last year. Next year we can expect Europe's lowest personal income tax, corporate income tax unchanged at 9 percent and small enterprise tax reduced to 13 percent. The tax allowance for families with two children will increase to HUF 35,000 per month, and HUF 226 billion will be earmarked for the housing programme. Pensions will be increased by the planned inflation rate and, moreover, a pension premium is also in the pipeline depending on economic performance.

I emphasized that the macroeconomic precondition for all of these provisions is to achieve 4.3 percent growth in the economy, a 2.4 percent government deficit, 3 percent inflation and a further reduction in the government debt-to-GDP ratio. "Can a better future be hoped for? Can welfare and income conditions be shaped 
more favourably than this?” I questioned the audience. Barely. Hungarian society has advanced from the negative to the positive domain. Remember that by 2008, after six years of liberal government, Hungary's economy had collapsed. It was rolling and tossing from a USD 25 billion loan granted by the IMF, the World Bank and the European Central Bank until 2010, which we were saddled with by the socialists under the leadership of Gyurcsány and Bajnai. At that time, the economy contracted by nearly 10 percent, pensions were on the decrease, the number of unemployed rose, and the conditions for starting a family and raising children deteriorated. Families, local governments and the government budget were burdened with foreign currency loans. There was unprecedented indebtedness at every level. This nightmare period is now a thing of the past.

The consolidation of welfare and labour-market conditions is hallmarked by the wage agreement signed for 2017 by the government as the coordinator of labourmarket processes with the involvement of employers and employees, the effects of which are already being felt. The minimum wage for unskilled workers has increased by 15 percent, and skilled workers' guaranteed minimum wage by 25 percent, while the employers' contribution was at the same time reduced by 5 percentage points. In 2018 these favourable developments will continue. The minimum wage for unskilled workers will increase by another 8 percent, and we can expect a 12-percent rise in the minimum wage for secondary-school graduates and a 2-percentage point drop in the employers' contribution.

If I were asked to sum up Hungarian budgetary developments, I would characterized them as reliable and stable. The country's government is capable of adopting the budget act six months before the start of the next year to ensure the conditions for forward-looking management by families and companies alike. Through wage agreements and welfare and child benefit funds, stable public finances are turning the years following fiscal and monetary consolidation into a budget for the employed. Through the retention of economic growth, a further increase can be expected in incomes.

The key to the success achieved so far is the political authorization granted by the overwhelming majority of the voters during every general election since 2010, which provides the basis for stable government. The operation of the rightist government and its extension from election to election is legitimized by citizens through the stability of their incomes and by corporations through the stability of their operations. "However, the continuation may be jeopardized," I confronted the audience with the cold facts. Several millions migrants are waiting along the borders, specifically at the Hungarian checkpoints at Röszke and Horgos and along the Italian coasts, for admission to a Europe known for more than fifty years for its internal peace, consolidated society and the security of human life and the economy. Their road does not take them here by chance: they are backed by business circles interested in weakening Europe, including Hungary.

On thousand and one hundred years ago, in the period of King St. Stephen, Hungary encountered similar public troubles. Domestic divisions, powers intending to subdue the Hungarians who had recently conquered the territory as their homeland 
and hosts of wars. King St Stephen responded by laying the foundations of the Hungarian state, reinforcing Christianity and setting up the county administration.

After two lost wars, forty years of soviet occupation and the concomitant foreign society and economy, and two decades of unsuccessful neoliberal attempts at transition to a market-economy, Hungary needs to be rebuilt. A new Fundamental Law and essential laws in finance were adopted to create the preconditions for economic stability in the country. Public administration had to be reorganized, a society built on work and an economic policy needed to be created that is open to the changing world while enforcing national characteristics along with the appropriate economic education. King St Stephen's reign was also disturbed by factional people, who failed or did not want to see the significance of Hungarians' survival, just as we have factional internal enemies who wish to put us to the sword to retain their obsolete ideas and the related financial gains. Our achievements are at stake. Just as in the period of the great king, we need the persistence of Christians and intellectuals to stand up for the country - Hungary is calling for help today. Within and across the borders. We need our communities to unite and close themselves off, and the skeptical to be convinced by reasonable arguments and kept in the flock. We can only remain strong if we retain our religion and faith in Hungary. And we badly need this as not only the successes of the past seven years but also the Hungarian state built during a thousand and one hundred years and the achievements of the Reformation have been put under threat.

Filling this struggle with academic knowledge is the service provided by the editorial board of Polgári Szemle and our authors. The studies published in this issue touch upon the academic presentation of our achievements, the effects of the family foundation and housing support in increasing the number of births, the budgetary and social achievements of central price regulation (cut in utility prices), and about King St Stephen's laws in a European context authored by the academic Gábor Hamza, member of the Hungarian Academy of Sciences.

I wish you pleasant reading and wholesome intellectual pleasure!

Professor Csaba Lentner, Editor-in-chief of Polgári Szemle 